\title{
RANCANG BANGUN ALAT PENYIRAM KECAMBAH OTOMATIS MENGGUNAKAN STM32F746G DISCOVERY DENGAN METODE FUZZY LOGIC CONTROL
}

\author{
Agus Ilham Palwa Samudra' ${ }^{1)}$, Misbah') \\ ${ }^{1,2)}$ Jurusan Teknik Elektro, Fakultas Teknik, Universitas Muhammadiyah Gresik \\ 1agusilhampalwa@gmail.com, ${ }^{2}$ misbah@umg.ac.id \\ J1. Sumatra No 101, Gresik 61121, Jawa Timur, Indonesia
}

\begin{abstract}
ABSTRAK
Proses pembuatan kecambah dari kacang hijau dibutuhkan proses penyiraman yang berkesinambungan. Penyiraman dimulai ketika suhu dan kelembapan tanaman kacang hijau mencapai mencapai parameter yang ditentukan dengan suhu $34{ }^{\circ} \mathrm{C}$ dan kelembapan $\pm 80 \%$. Karena pada keadaan itu, kacang hijau bisa tumbuh optimal. Ketika parameter mencapai setpoint menyebabkan kacang hijau mudah membusuk sementara ketika suhu kurang dari $30{ }^{\circ} \mathrm{C} 50 \% \mathrm{RTH}$ pertumbuhan kacang hijau menjadi kecambah akan melambat.. Pada skripsi ini dibuat sebuah inverter full bridge satu fasa menggunakan metode switching SPWM untuk mengendalikan kecepatan motor induksi satu fasa untuk proses penyiraman tanaman kecambah. Selain itu, kontrol logika fuzzy (FLC) digunakan sebagai kontrol untuk mengklasifikasikan frekuensi output dari inverter berdasarkan suhu dan kelembapan yang di baca. Dengan FLC maka debit air yang disiramkan untuk proses penyiraman dapat diatur untuk menjaga keakuratan pada suhu $34{ }^{\circ} \mathrm{C}$ sampai $30{ }^{\circ} \mathrm{C}$ atau $50 \%$ - 80\% RTH. Seiring dengan penurunan suhu dan kelembapan kecambah akibat proses penyiraman yang dilakukan terjadi perubahan frekuensi secara otomatis pada output inverter antara $50 \mathrm{~Hz}-$ $30 H z$. Pengaturan kecepatan dengan cara mengklasifiksikan frekuensi berdasarkan parameter menggunakan kontrol logika fuzzy dapat menjaga suhu dan kelembaban sesuai parameter dengan waktu proses penyiraman selama \pm 5 Menit.
\end{abstract}

Kata-kata kunci: Suhu, Kelembaban, Kontrol Logika Fuzzy, Inverter 1 phasa

\section{PENDAHULUAN}

Kegiatan pertanian budidaya kecambah dalam pembuatannya membutuhkan disiplin dan konsitensi. Proses pertumbuhan kecambah dari biji kacang hijau sebagai benih membutukan penyiraman 12 kali dalam sehari selama 3 hari untuk menghasilkan kualitas kecambah yang baik. Pembaharuan teknologi dari penyiraman dari tradisional ke modern diperlukan guna meningkatkan kinerja dan hasil dari pertanian kecambah.

Seiring perkembangan teknologi, pembaharuan suatu sistem penyiram otomatisasi tentu sangat membantu dalam memudah proses pertanian kecambah. Pada jurnal penelitian sebelumnya tentang alat penyiram kecambah otomatis hybrid disebutkan memiliki 2 sumber yaitu 220 Volt jala - jala PLN dan baterai yang di charge menggunakan solar cell. Penggunaan inverter satu fasa dengan metode switching SPWM untuk pengendalian motor induksi 1 fasa pada proses penyiraman. Fuzzy Logic Control (FLC) digunakan sebagai kontrol untuk mengklasifikasikan output inverter berdasarkan sensing dari sensor suhu LM-35, namun terdapat beberapa kekurangan diantaranya pembacaan sensor yang kurang maksimal dan sering terjadinya drop tegangan [1]. 
Maka dari itu, pembaharuan teknologi penyiraman otomatis dangan pembuatan alat penyiram otomatis menggunakan sensor SHT11 dan inverter full-bridge satu fasa dengan Fuzzy Logic Control (FLC) untuk mengatur output penyiraman yang dihasilkan pada alat berdasarkan sensing sensor SHT11.

\section{METODE}

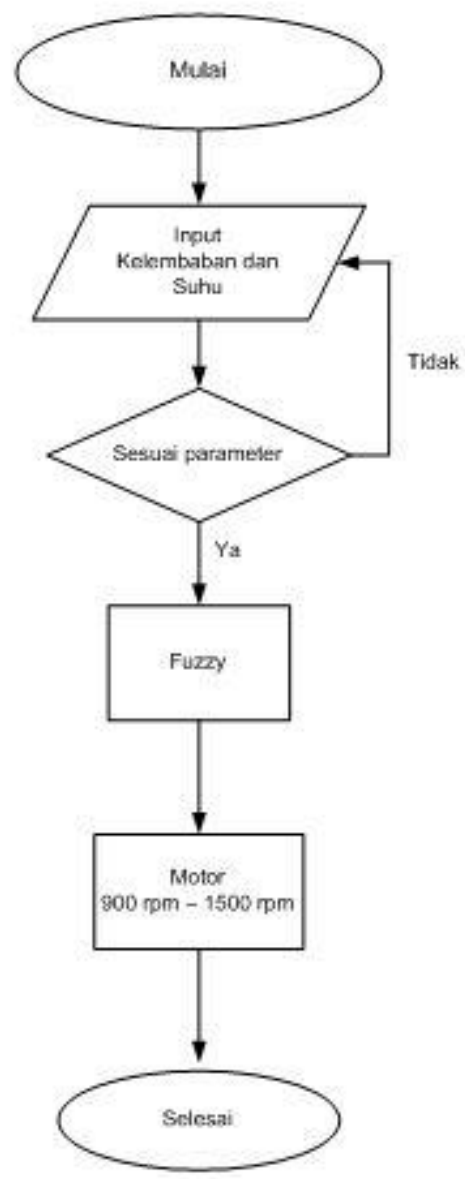

Gambar 1. Flow Chart Sistem Penyiram Kecambah Otomatis

Perancangan sistem alat penyiram kecambah otomatis memiliki sumber jala jala 220 Volt yang disearahkan oleh rectifier tak terkontrol dan distabilkan dengan DCLink. Inverter full-bridge satu fasa menggunakan modulasi Sinusoidal Pulse With Modulation (SPWM) yang dibangkitkan STM32F746VG Discovery dan proses switching pada inverter menggunakan IC IR2111 untuk memisahkan periode high node dan low sinyal SPWM. Gelombang yang dihasilkan inverter tidak sinus maka, dibutuhkan Low Pass Filter agar output gelombang mendekati sinus murni.

Sistem bekerja berdasar kan 2 buah input suhu (T) dan kelembaban (R) dari sensor SHT11, data dari input akan diolah oleh ARM STM32F746G Discovery dengan logika Fuzzy. Logika fuzzy Tsukamoto digunakan sebagai kontrol untuk mengklasifikasikan frekuensi output motor induksi 1 fasa. Sistem ini menghasilkan output yang dapat menghidupkan motor secara otomatis yang dikendalikan oleh ARM STM32F746G dengan menggunakan SPWM, selain itu hasil pembacaan sensor akan ditampilkan pada LCD Touchscreen ARM STM32F746G yang dapat bertindak sebagai kontrol manual tanpa sistem otomatis.

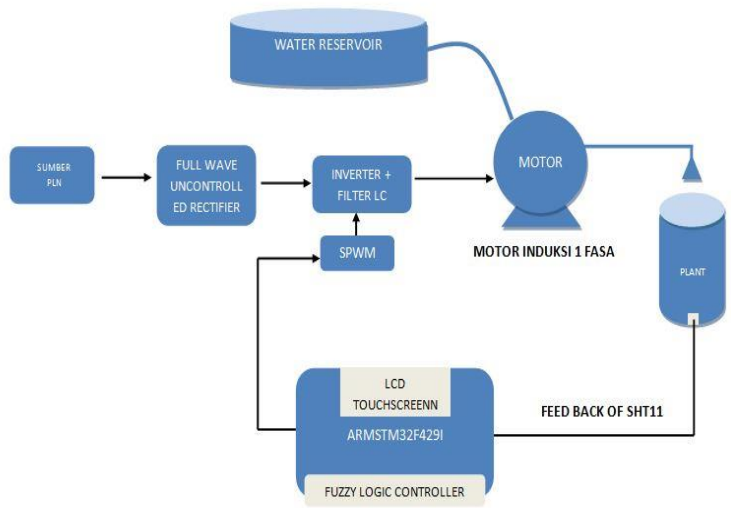

Gambar 2. Blok Diagram Sistem

\subsection{Perancanaan Inverter Full-brigde satu fasa}

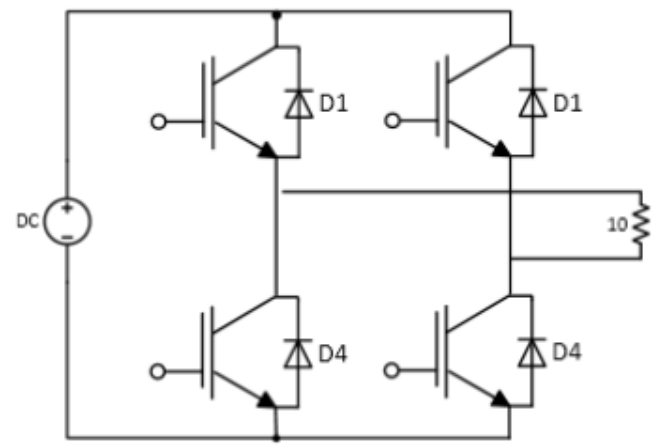

Gambar 3. Rangkaian Inverter dengan 4 buah IGBT

Rangkaian inverter menggunakan 4 buah komponen switching IGBT (Insulated 
Gate Bipolar Transistor) yang bekerja sedemikian rupa bersama untuk menghasilkan gelombang AC. Tipe komponen yang digunakan IGBT Toshiba MG150J2YS50 dan 200J2YS50, gambar 2. menunjukan rangkain inverter menggunakan 4 buah IGBT.

Proses switching IGBT menggunakan metode SPWM dengan membandingkan gelombang segitiga dengan gelombang sinus yang nantinya dikirim ke gate IGBT. Frekuensi sinus yang digunakan $50 \mathrm{~Hz}$ yang merupakan nilai output inverter, sedangkan frekuensi segitiga yang digunakan $13 \mathrm{kHz}$. Pada metode switching SPWM dapat dicari rasio modulasi amplitude dan juga modulasi frekuensi yaitu dengan rumus dibawah ini :

$$
\begin{aligned}
& M_{a}=\frac{A c}{A m} \\
& M_{a}=1 / 1=1
\end{aligned}
$$

Dimana :

$A_{c}=$ Amplitude Carrier (delta)

$A_{m}=$ Amplitude Sinus

$$
M_{f}=\frac{f_{c}}{f_{m}}
$$

Dimana :

$F_{m}=$ Frekuensi Sinus

$$
F_{c}=\text { Frekuensi Carrier (delta) }
$$

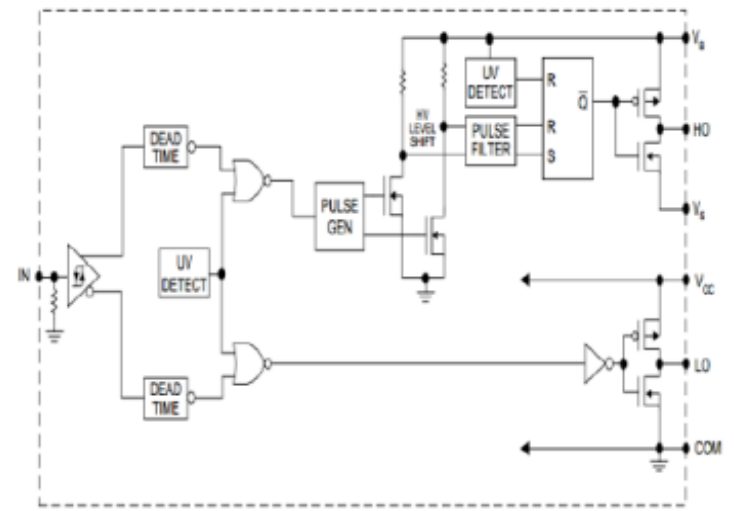

Gambar 4. Rangkaian Functional Diagram Block IR2111

Proses drive inverter satu fasa membutuhkan output minimal 10 Volt, karena output sinyal SPWM yan dibangkitkan oleh ARMSTM32F7 hanya 3 hingga 5 Volt. Maka, dibutuhkan rangkaian Functional Diagram Block IR2111 sebagai tambahan untuk mendrive inverter [2]. Gambar 3. Menunjukan rangkaian Functional Diagram Block IR2111

\subsection{Perencanaan Filter LC}

Penggunaan filter pasif LC atau filter low pass adalah untuk menfilter gelombang keluaran inverter yang tidak sinus menjadi sinus yang berusaha bekerja pada frekuensi $50 \mathrm{~Hz}$.

\subsubsection{Penenetuan Nilai Kapasitor}

Penentuan nilai kapasitor ini diharapkan power factor sistem tidak terlalu bersifat induktif dan tidak terlalu bersifat kapasitif, karena dapat menyebabkan voltage spike maupun current spike. Pada penelitian ini ditentukan langsung nilai kapasitornya sebesar $6 \mathrm{uF}$.

\subsubsection{Penentuan Nilai Induktor}

Pada penentuan nilai induktor ini diharapkan antara induktor dan kapasitor akan teradi resonansi sehingga $X l=X c$. Pada penentuan nilai inductor ini perlu ditentukan terlebih dahulu frekuensi cut off dari filter. Pada penelitian ini ditentukan frekuensi $c u t$ off nya adalah $3000 \mathrm{~Hz}$. Sehingga nilai induktor adalah sebagai berikut :

$F_{C}=\frac{1}{2 \pi \sqrt{L C}}$

$L=\frac{1}{4 \pi f_{C}^{2} C}=L=\frac{1}{(2.3,14.3000)^{2} .6}=469,565 \mu \mathrm{H}$ $\sim 500 \mu \mathrm{H}$

Nilai induktor 469,565 uH harus dibuat dengan nilai yang fix agar memudahkan dalam pembuatan induktor. Sehingga nilai 469,565 uH akan dibulatkan menjadi $500 \mathrm{uH}$ dan penggunaan inductor berbahan toroid untuk Low Pass Filter yang terdiri dari induktor yang dirangkai seri dan kapasitor yang dirangkai paralel. 


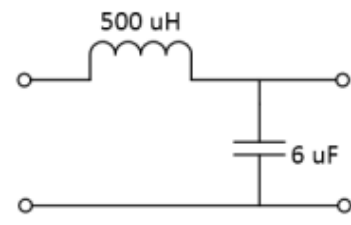

Gambar 5. Rangkaian Filter LC

Rangkaian Low Pass Filter pada gambar 4. diharapkan mampu menfilter harmonisa yang dihasilkan dari inverter dikarenakan signal output dari inverter nonsinus. Low Pass Filter diatas secara teori direncanakan memiliki frekuensi cut off sebesar $3000 \mathrm{~Hz}$ yang artinya Low Pass Filter akan melewatkan frekuensi dibawah $3000 \mathrm{~Hz}$ dan akan menahan frekuensi dibawah 3000 Hz. Sehingga secara teori dari frekuensi cut off sebesar $3000 \mathrm{~Hz}$ tersebut mampu melewatkan tegangan fundamental dari tegangan harmonisa yang dihasilkan oleh output inverter sehingga menghasilkan tegangan output sinus.

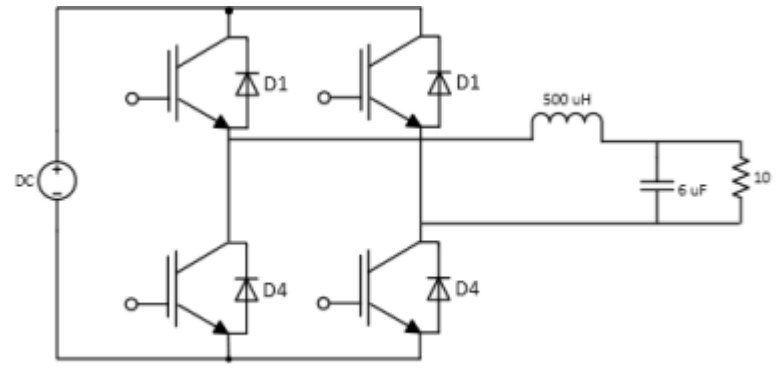

Gambar 6. Rangkaian Inverter dan Low Pass Filter

Rangkaian tersebut akan digabungkan dengan rangkaian inverter satu fasa untuk menghasilkan gelombang sinus yang mengubah gelombang kotak keluaran dari inverter ditunjukkan pada gambar 5 .

\subsection{Perencanaan Full Wave Uncontroller Rectifier}

Tegangan $220 \mathrm{~V}$ dari jala - jala PLN akan digunakan sebagai sumber dari inverter setelah disearahkan menjadi tegangan DC oleh Full Wave Uncontrolled Rectifier sebesar 311 Vdc yang diambil dari output rectifier.

Penngunaan diode bridge 10 A dengan 5 buah kapasitor elco $220 \mu \mathrm{f} 450$ Volt yang dirangkai seri dipilih untuk memberikan suplai pada DC pada modul inverter 1 fasa.

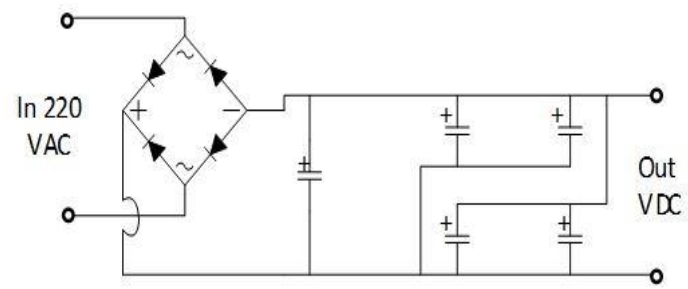

Gambar 7. Rangkaian Penyearah tak terkontrol

\subsection{Perencanaan Motor Induksi 1 Fasa}

Motor induksi satu fasa sebagai penggerak pompa air guna untuk menyiram kecambah, untuk itu harus ditentukan spesifikasi motor induksi satu fasa yang akan digunakan.

Penentuan daya motor induksi satu fasa dapat dilakukan dengan melakukan perhitungan daya motor sesuai dengan daya pada beban yang akan digunakan pada plant. Dan untuk Plant ini karena hanya akan di bebani dengan penyiraman pada kecambah maka ditentukan spesifikasi motor induksi 1 fasa yang akan digunakan sebagai berikut :

1. Daya $=25$ Watt

2. Tengangan nominal $=220$ Volt

3. Arus nominal $=1,55$ Ampere

\subsection{Perencanaan Metode Fuzzy Tsukamoto}

1. Proses awal dilakukan dengan menentukan masing criteria yaitu: Suhu dan Kelembaban.

2. Kemudian dari criteria tersebut dilanjutkan dengan menentukan implikasi dari masing - masing kriteria (menentukan himpunan dari masing - masing variabel).

3. Proses perhitungan fungsi derajat keanggotaan dengan kurva dari setiap criteria variabel yang nantinya digunakan sebagai 
pembobotan nilai dari masingmasing kriteria.

4. Dari himpunan tersebut dilakukan proses perhitungan nilai derajat keanggotaan dari variabel yang akan digunakan sebagai pembobotan nilai dari masing - masing criteria dari implikasi setiap aturan.

5. Menentukan 20 aturan dimana didapat probabilitas implikasi dari masing - masing criteria untuk menentukan nilai dari $\alpha$ predikat ke-i.

6. Dari 20 aturan ditentukan perhitungan nilai zi $\mathrm{x} \alpha$-predikat ke-i.

7. Proses perhitungan nilai rata-rata $\mathrm{z}$ dengan rumus sebagai berikut $\sum\left(\right.$ zi x $\alpha$-predikat ke-i) $/ \sum(\alpha-$ predikat ke-i).

8. Dari hasil perhitungan nilai average $\mathrm{z}$ aturan maka didapatkan nilai akhir berupa putaran motor.

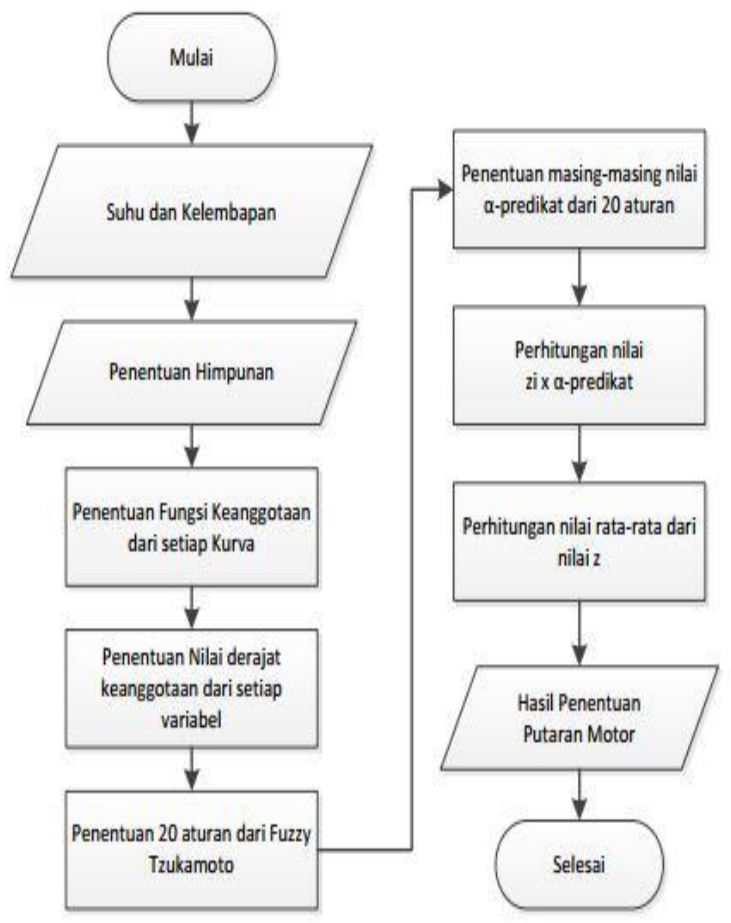

Gambar 8. Flow Chart Fuzzy Tsukamoto

\subsubsection{Pembentukan Himpunan Fuzzy dan Aplikasi Fungsi Implikasi}

1. Suhu

: Dingin, Sejuk, Normal, Hangat, Panas

2. Kelembaban : Kering, Normal, Lembab, Sangat Lembab

\subsubsection{Derajat Keanggotaan Fuzzy}

Derajat keanggotaan merupakan suatu kurva yang menunjukkan pemetaan titik titik input data kedalam nilai keanggotaannya (fungsi keanggotaan), fungsi keanggotaan memiliki interval nilai anatara 0 dan 1 , adapun untuk mendapatkan nilai keanggotaan dapatdilakukan dengan pendekatan fungsi sebagai berikut :

\section{Suhu $(\mathrm{T})$}

- Himpunan Dingin, batas 0 - 30 31 menggunakan kurva turun.

- Himpunan Sejuk, batas 30 - 31 32 menggunakan kurva segitiga.

- Himpunan Normal, batas 30 - 3233 menggunakan kurva segitiga.

- Himpunan Hangat, batas 32 -33 34 menggunakan kurva segitiga.

- Himpunan Panas, batas 33 - 34 100 menggunakan kurva naik.

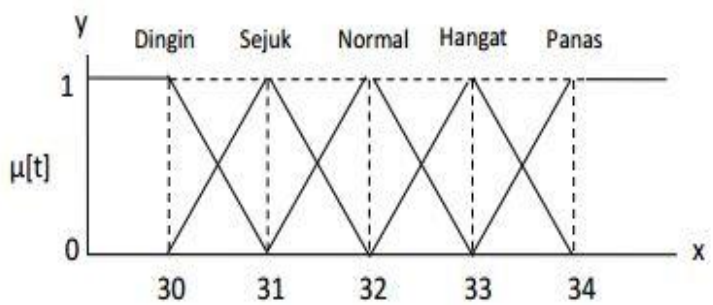

Gambar 9. Grafik Kurva Fuzzy Suhu

\section{Kelembaban (R)}

- Himpunan Kering, batas 0-50-60 menggunakan kurva turun.

- Himpunan Normal, batas 50-6070 menggunakan kurva segitiga.

- Himpunan Lembab, batas 60-7080 menggunakan kurva segitiga.

- Himpunan Sangat Lembab, batas 70-80-90 menggunakan kurva naik. 


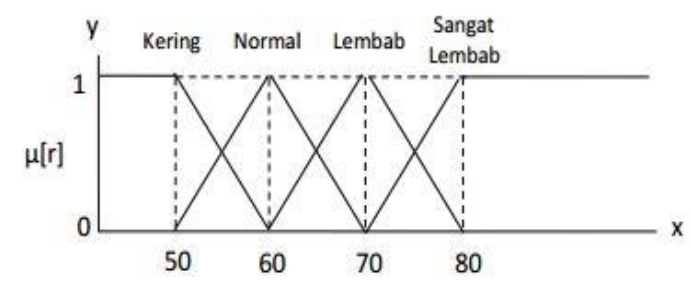

Gambar 10. Grafik Kurva Fuzzy Kelembaban

\section{Frekuensi (f)}

- Himpunan Low, batas 0-30-40

- Himpunan Medium, batas 30-4050

- Himpunan Fast, batas 40-50

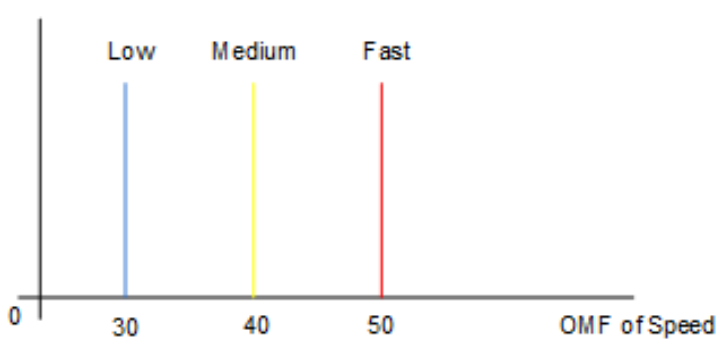

Gambar 11. Output Frekuensi Motor

\section{HASIL DAN DISKUSI}

\subsection{Pengujian Motor Induksi 1 Fasa}

Pengujian motor induksi satu fasa ini dilakukan untuk mengetahui arus yang bekerja pada motor, tegangan motor, dan juga kecepatan motor. Pengujian motor induksi satu fasa ini dilakukan dengan memberi tegangan input motor 220 Volt dari jala - jala PLN dilakukan pengukuran dengan voltmeter, amperemeter, dan kecepatan motor dengan tachometer.

Hasil Pengujian Motor Induksi 1 Fasa

\begin{tabular}{ccc}
\hline Volt & Ampere & Rpm \\
\hline $221,5 \mathrm{~V}$ & $1,1 \mathrm{~A}$ & 2969
\end{tabular}

\subsection{Pengujian Penyearah Tak Terkontrol}

Pengujian ini menggunakan sumber 220 Volt jala-jala PLN ke Penyearah Tak Terkontrol.
Pengujian Penyearah Tak Terkontrol

\begin{tabular}{ll}
\hline $\mathrm{V}$ in $(\mathrm{AC})$ & $\mathrm{V}$ out (DC) \\
\hline $220 \mathrm{Vac}$ & $331 \mathrm{Vdc}$
\end{tabular}

\subsection{Pengujian Inverter 1 Fasa dan Low Pass Filter Beban Lampu Pijar}

Komponen switching inverter IGBT (Insulated Gate Bipolar Transistor) yang mengubah sinyal AC menjadi sinyal DC. Metode switching yang digunakan adalah metode SPWM (Sinusodial Pulse With Modulation) yang dibangkitkan oleh ARM STM32F746G Discovery yang selanjutnya akan di drive oleh driver inverter untuk memisahkan output low dan output high.

Terdapat dua buah IC IR2111 dan 2 buah IC TLP521 yang berfungsi memisahkan output low dan output high dari SPWM yang dibangkitkan mikrokontroler. Output dari rangkaian driver berupa 2 output untuk 2 buah IGBT yang berpasangan yaitu output low dan output high dengan amplitudo 12 Volt sesuai dengan Vcc.

Tabel 1. Pengujian Inverter dan Low Pass Filter

\begin{tabular}{ccccc}
\hline $\begin{array}{c}\text { Vin } \\
\text { Inverter }\end{array}$ & $\begin{array}{c}\text { Vout } \\
\text { Inverter }\end{array}$ & $\begin{array}{c}\text { Vout } \\
\text { LPF }\end{array}$ & $\begin{array}{c}\text { Vout } \\
\text { Teori }\end{array}$ & $\begin{array}{c}\text { Error } \\
(\%)\end{array}$ \\
\hline \multirow{2}{*}{$20 \mathrm{Vdc}$} & 13,66 & 13,51 & 14,14 & 3,4 \\
& Vac & Vac & Vac & 3,45 \\
$22 \mathrm{Vdc}$ & 15,9 & 14,93 & 15,55 & 2,25 \\
& Vac & Vac & Vac & \\
$24 \mathrm{Vdc}$ & 16,55 & 16,41 & 16,97 & 2,4 \\
& Vac & Vac & Vac & \\
$26 \mathrm{Vdc}$ & 18,01 & 17,88 & 18,38 & 1,7 \\
& Vac & Vac & Vac & \\
\hline
\end{tabular}

Karena output inverter masih nonsinus sehingga tidak dimungkinkan untuk melakukan pengujian maka, dilakukan dengan cara menghubungkan inverter dengan Low Pass Filter sehingga output mendekati sinus murni dengan cara mengubah - ubah tegangan masukan menggunakan Power Supply DC, pengujian dapat dilihat pada Tabel 3. 
Grafik Pengujian Inverter dan Low Pass Filter

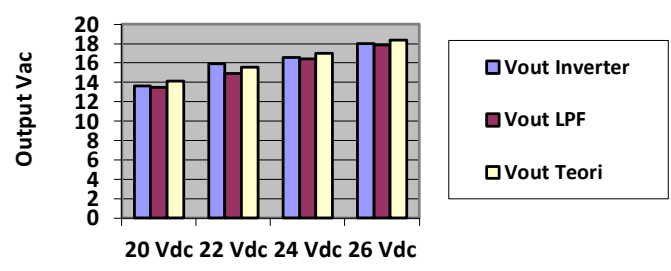

Input Vdc

Gambar 12. Hasil Pengujian Inverter 1 Fasa dan Low Pass Filter

\subsection{Pengujian Sensor SHT 11} Kelembaban dan Suhu

SHT11 waterproof. Pengujian ini dilakukan mengetahui kepresisian nilai suhu yang dihasilkan dari pembacaan sensor.

Tabel 2. Pengujian Sensor SHT 11 Suhu

\begin{tabular}{ccc}
\hline $\begin{array}{c}\text { Temperatur } \\
\text { Termometer }\end{array}$ & $\begin{array}{c}\text { Temperatur } \\
\text { SHT }\end{array}$ & $\begin{array}{c}\text { Error } \\
\%\end{array}$ \\
\hline $30^{\circ}$ & $30,7^{\circ}$ & $2,33 \%$ \\
$31^{\circ}$ & $31,1^{\circ}$ & $0,32 \%$ \\
$32^{\circ}$ & $32,3^{\circ}$ & $0,94 \%$ \\
$33^{\circ}$ & $33,3^{\circ}$ & $0,91 \%$ \\
$34^{\circ}$ & $33,9^{\circ}$ & $0,29 \%$
\end{tabular}

Pengujian dilakukan dengan cara membandingan ke dua input SHT11 suhu dan kelembaban dengan input dari termometer dan hygronometer untuk mengetahui kepresisian deteksi dari sensor SHT11. Dengan rumus (Temp. Termo - Temp. SHT)/Temp. Termo.

Tabel 3. Pengujian Sensor SHT11 Kelembaban

\begin{tabular}{ccc}
\hline $\begin{array}{c}\text { Humidity } \\
\text { Hygronometer }\end{array}$ & $\begin{array}{c}\text { Humidity } \\
\text { SHT }\end{array}$ & $\begin{array}{c}\text { Error } \\
(\%)\end{array}$ \\
\hline $62 \% \mathrm{RH}$ & $63 \%$ & $1,61 \%$ \\
$62 \% \mathrm{RH}$ & $62 \%$ & $0 \%$ \\
$57 \% \mathrm{RH}$ & $57 \%$ & $0 \%$ \\
$53 \% \mathrm{RH}$ & $53 \%$ & $0 \%$ \\
$50 \% \mathrm{RH}$ & $50 \%$ & $0 \%$
\end{tabular}

\subsection{Pengujian Integrasi Sistem}

Pengujian parsial tiap komponen dibutuhkan dengan dilakukan penyatuan seluruh komponen. Pengaturan kecepatan motor dilakukan dengan pengaturan frekuensi inverter berdasarkan pada perubahan suhu dan kelembaban pada plant.

Tabel 4. Hasil Pengujian Integrasi Sistem Close Loop

\begin{tabular}{|c|c|c|c|}
\hline SHT 11 & $\begin{array}{c}\text { Frekuensi(P) } \\
(\mathrm{Hz})\end{array}$ & $\begin{array}{l}\text { Teori } \\
(\mathrm{Hz})\end{array}$ & $\begin{array}{c}\text { Error } \\
\%\end{array}$ \\
\hline $\begin{array}{c}30,2^{\circ} \mathrm{C} 79 \% \\
\mathrm{RH}\end{array}$ & 31 & 32.5 & $\begin{array}{c}4.62 \\
\%\end{array}$ \\
\hline $\begin{array}{l}30,51^{\circ} \mathrm{C} \\
76 \% \mathrm{RH}\end{array}$ & 32 & 32.7 & $\begin{array}{c}2.14 \\
\%\end{array}$ \\
\hline $\begin{array}{c}31^{\circ} \mathrm{C} 74 \% \\
\mathrm{RH}\end{array}$ & 34 & 34.8 & $\begin{array}{c}2.30 \\
\%\end{array}$ \\
\hline $\begin{array}{l}31,51^{\circ} \mathrm{C} \\
70 \% \mathrm{RH}\end{array}$ & 36 & 36.12 & $\begin{array}{c}0.33 \\
\%\end{array}$ \\
\hline $\begin{array}{l}32,01^{\circ} \mathrm{C} \\
69 \% \mathrm{RH}\end{array}$ & 38 & 39.2 & $\begin{array}{c}3.06 \\
\%\end{array}$ \\
\hline $\begin{array}{c}32,4^{\circ} \mathrm{C} 65 \% \\
\mathrm{RH}\end{array}$ & 40 & 41.2 & $\begin{array}{c}2.91 \\
\%\end{array}$ \\
\hline $\begin{array}{l}33,52^{\circ} \mathrm{C} \\
60 \% \mathrm{RH}\end{array}$ & 44 & 45 & $\begin{array}{c}2.22 \\
\%\end{array}$ \\
\hline $\begin{array}{c}34^{\circ} \mathrm{C} 56 \% \\
\mathrm{RH}\end{array}$ & 48 & 47.6 & $\begin{array}{c}0.84 \\
\%\end{array}$ \\
\hline $\begin{array}{l}34,51^{\circ} \mathrm{C} \\
50 \% \mathrm{RH}\end{array}$ & 50 & 49.8 & $\begin{array}{c}0.40 \\
\%\end{array}$ \\
\hline \multicolumn{3}{|c|}{ Rata - Rata } & $\begin{array}{c}2.09 \\
\%\end{array}$ \\
\hline
\end{tabular}

Dibawah ini merupakan grafik dari hasil pengujian integrase sistem alat penyiram otomatis sistem close loop.

\section{Pengujian Sistem Close Loop}

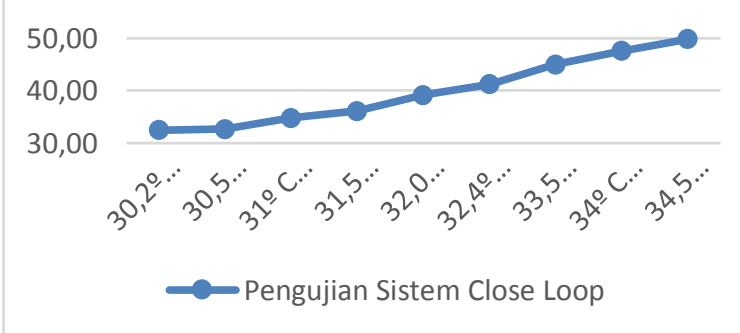

Gambar 13. Hasil Pengujian Sistem Close Loop 
Selanjutnya yaitu dengan pengujian sistem open loop. Pengujian ini dilakukan untuk mengetahui besar daya yang dihasilkan inverter untuk mensuplai motor induksi 1 fasa dan untuk mengetahui besarnya drop tegangan akibat pembebabanan motor induksi 1 fasa yang dibebani penyemprotan air ke plant.

Tabel 5. Hasil Pengujian Integrasi Sistem Open Loop

\begin{tabular}{cccccc}
\hline $\begin{array}{c}\text { Vin(DC) } \\
\text { Inverter } \\
\text { (V) }\end{array}$ & $\begin{array}{c}\text { Idc } \\
(\mathrm{A})\end{array}$ & $\begin{array}{c}\text { Vo } \\
(\mathrm{V})\end{array}$ & $\begin{array}{c}\text { Io } \\
(\mathrm{A})\end{array}$ & $\eta$ & Beban \\
\hline 33,3 & 3,1 & $\begin{array}{c}221, \\
9\end{array}$ & $\begin{array}{c}0,4 \\
8\end{array}$ & $\begin{array}{c}62 \\
\%\end{array}$ & $\begin{array}{c}\text { Tanpa } \\
\text { beban }\end{array}$ \\
& & & & 86, & \\
33,1 & 6,1 & $\begin{array}{c}218, \\
5\end{array}$ & 1 & $\begin{array}{c}57 \\
\%\end{array}$ & Beban \\
& & 5 Motor \\
\hline
\end{tabular}

Dari hasil pengujian didapat perhitungan efisiensi inverter dan efisiensi sistem secara keseluruhan. Untuk perhitungannya sebagai berikut :

\section{Tanpa Beban}

\section{Efisiensi}

Pin DC $=\operatorname{Vin}(\mathrm{dc}) \times \operatorname{Idc}=33,3 \times 3,1=$ $103,23 \mathrm{~W}$

Pout $\mathrm{AC}=$ Vo $\mathrm{x}$ Io $\mathrm{x}$ Cosphi $=211 \mathrm{x}$ $0,48 \times 0,62=64,88 \mathrm{~W}$

$$
\eta=\mathrm{Po} / \mathrm{Pin} \times 100 \%=64,88 / 103,23=
$$
$62 \%$

\section{Beban Motor}

\section{Efisiensi}

Pin DC $=$ Vin $(d c) \times I d c=33,1 \times 6,1=$ 201,9 W

$$
\text { Pout } \mathrm{AC}=\text { Vo } \mathrm{x} \text { Io } \mathrm{x} \text { Cosphi }=218,5
$$

$$
\begin{aligned}
& \text { x } 1 \times 0,78=174,8 \mathrm{~W} \\
& \quad \eta=\text { Po } / \operatorname{Pin} \times 100 \%=174,8 / 201,9 \\
& =86,57 \%
\end{aligned}
$$

Dari data diatas dapat dilihat tidak terdapat penurunan tegangan pada sisi output yang membuat efisiensi dari inverter tinggi sehingga inverter dapat mengeluarkan daya maksimum untuk mensuplai motor induksi 1 fasa, terbukti pada tegangan output sebesar 218,5 Volt yang mana tegangan mendekati 220 Volt.

Pengujian pertumbuhan kecambah pada hari ke 1 sampai ke 5, pada panen pertama hingga ke lima pertumbuhan kecambah yang mendapatkan perlakuan alat atau pun tidak pertumbuhannya sangat bervariasi, namum pertumbuhan kecambah yang mendapatkan perlakuan alat memiliki rata - rata yang lebih tinggi dari pada kecambah yang tidak mendapat perlakuan alat.

Tabel 6. Hasil Panen Kecambah Panen ke 1 5

\begin{tabular}{|l|l|c|c|}
\hline \multirow{2}{*}{ No. } & \multirow{2}{*}{ Waktu Panen } & Sistem & Non-Sistem \\
\cline { 3 - 4 } & & $\begin{array}{l}\text { Pembusukan } \\
(\%)\end{array}$ & $\begin{array}{l}\text { Pembusukan } \\
(\%)\end{array}$ \\
\hline 1. & Panen ke 1 & 1.29 & 4.21 \\
\hline 2. & Panen ke 2 & 3.54 & 1.07 \\
\hline 3. & Panen ke 3 & 2.09 & 3.89 \\
\hline 4. & Panen ke 4 & 1.71 & 2.54 \\
\hline 5. & Panen ke 5 & 1.05 & 1.78 \\
\hline & Rata - Rata & 1.9 & 2.6 \\
\hline
\end{tabular}

\section{KESIMPULAN}

Dari semua perancangan, pembuatan, dan pengujian baik yang dilakukan dengan per bagian ataupun yang dilakukan dengan cara sistem terintegrasi dapat disimpukan beberapa hal sebagai berikut :

1. Pompa air mulai ON secara otomatis pada saat suhu dan kelembaban mencapai $>34^{\circ} \mathrm{C} 50 \% \mathrm{RH}$ dan $\mathrm{OFF}$ scara otomatis pada keadaan $<30^{\circ} \mathrm{C}$ $63 \%$ RH.

2. Dengan menggunakan Kontrol Logika Fuzzy (FLC) pengaturan debit air yang disiramkan dapat diatur mulai dari frekuensi $50 \mathrm{~Hz}-30 \mathrm{~Hz}$. 
3. Pada saat suhu mencapai $34^{\circ} 50 \% \mathrm{RH}$ frekuensi yang dikeluarkan inverter sebesar $50 \mathrm{~Hz}$.

4. Dengan Kontrol Logika Fuzzy keadaan suhu dan kelembaban dapat dijaga pada $<30^{\circ} \mathrm{C} 63 \% \mathrm{RH}$ setelah proses penyiraman berhenti.

5. Jika tanpa Kontrol Logika Fuzzy keadaan suhu dan kelembaban masih dibawah $30^{\circ} \mathrm{C} 63 \% \mathrm{RH}$.

6. Waktu penyiraman saat tanpa menggunakan Kontrol Logika Fuzzy membutuhkan waktu \pm 4 menit mencapai batas minimum.

7. Waktu penyiraman kecambah menggunakan control Logika Fuzzy membutuhkan waktu \pm 5 menit mencapai batas minimum.

8. Kecambah yang ditumbuhkan kurun waktu 2 hari sudah dapat dipanen dan dijual kepasar namun dibeberapa sisi masih mengalami pembusukan.

\section{DAFTAR PUSTAKA}

[1] R. B. I. Kurniawan, "Desain Dan Implementasi Inverter 1 Fasa Pada Alat Penyiram Kecambah Menggunakan Kontrol Logika Fuzzy," Politeknik Elektro Negeri Surabaya, 2018.

[2] F. Fajar, "Rancang Bangun Inverter Satu Fasa Untuk Alat Perontok Jagung Dengan Kontrol PID," Teknik Elektronika Industri PENS Surabaya, 2016.

[3] Ilmanda, H., \& Facta, M. (n.d.). (2014). Pembuatan catu daya arus dc menggunakan topologi inverter jembatan penuh dan penyearah. Teknik Elektro. Universitas Diponegoro.

[4] Samman, F. A., Ahmad, R., \& Mustafa, M. (2015). Perancangan , Simulasi dan Analisis Harmonisa Rangkaian Inverter Satu Fasa, 4(1), 62-70.
[5] Haryanto, H. (2011). Pembuatan Modul Inverter sebagai Kendali Kecepatan Putaran Motor Induksi Pendahuluan Metodologi Penelitian. Teknik Elektro. Universitas Sultan Agung Tirtoyoso.

[6] Sofwan, A. S. (2005). Penerapan Fuzzy Logic pada Sistem Pengaturan Jumlah Air Berdasarkan Suhu dan Kelembaban. ISBN : 979 - 756 - 061 -6 .

[7] Syahlul, M. (2015). Implementasi Sensor Suhu dan Kelembapan pada Pengaturan Kecepatan Putaran Motor Air Cooler dengan Metode Fuzzy Logic. Tugas Akhir Teknik Elektro. Politeknik Negeri Batam.

[8] Rosyada, D. Al., Misbah., \& Eliyani. (2016). Anfis Based Material Flow Rate Control System for Weigh Feeder Conveyor. Computer and International Science; Vol 9. Doi:10.5539/cis.v9n2p112.

[9] Kusumadewi, S., \& Purnomo, H. (2010). Aplikasi Logika Fuzzy Sebagai Pendukung Keputusan. Yogyakarta: GRAHA ILMU.

[10] Kusumadewi, S. (2006). Fuzzy Multi Attribute Decision Making. Yogyakarta: GRAHA ILMU

[11] F. Thamrin, E. Sediyono, and S. Suhartono. (2014). Studi Inferensi Fuzzy Tsukamoto Untuk Penentuan Faktor Pembebanan Trafo PLN," JSINBIS (Jurnal Sistem Informasi Bisnis), vol. 2, no. 1, pp. 001-005. doi.org/10.21456/vol2iss1pp001-005 